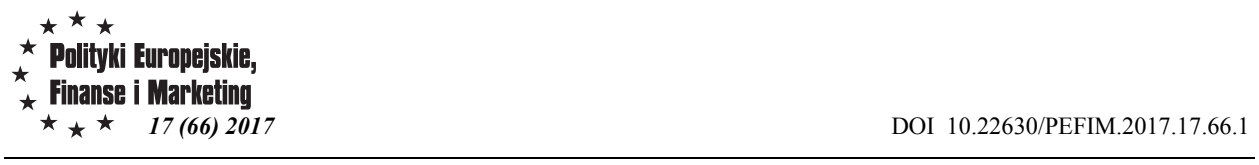

Mieczysław Adamowicz

Państwowa Szkola Wyższa im. Papieża Jana Pawla II w Bialej Podlaskiej

Wioletta Miklaszewska

Szkota Gtówna Gospodarstwa Wiejskiego w Warszawie

Tomasz Adamowicz

Państwowa Szkola Wyższa im. Papieża Jana Pawła II w Białej Podlaskiej

\title{
Światowy kryzys finansowy i dzialania naprawcze wobec gospodarki polskiej
}

\author{
WORLD FINANCIAL CRISIS AND ANTICRISIS \\ ACTIVITIES RELATED TO POLISCH ECONOMY
}

Przedmiotem pracy jest przedstawienie zarysu światowego kryzysu finansowego z lat 2007-2011, jego przebiegu $i$ skutków $w$ Polsce oraz działań naprawczych $i$ zapobiegawczych podejmowanych przez rzqd $i$ instytucje finansowe $w$ Polsce. Praca oparta na literaturze problemu $i$ przedmiotu badań oraz informacjach różnych krajowych $i$ międzynarodowych instytucji finansowych $i$ organizacji międzynarodowych. Kryzys finansowy $w$ Polsce ujawnit się $z$ opóźnieniem $w$ stosunku do innych krajów wysokorozwiniętych $i$ przebiegal $z$ mniejszq intensywnościq. $W$ działaniach antykryzysowych Polska dostosowała sie do zaleceń Unii Europejskiej. Międzynarodowego Funduszu Walutowego. Działania rzadu i banku centralnego w Polsce dotyczyly sfery instytucjonalnej, sposobu funkcjonowania i prowadzenia polityki finansowej oraz sfery realnej gospodarki, $w$ tym zwłaszcza przedsiębiorstw, gospodarstw domowych $i$ instytucji publicznych.

Słowa kluczowe: kryzys finansowy, wielka recesja, działania antykryzysowe, polityka finansowa

\section{Wstęp}

$\mathrm{Na}$ przestrzeni ostatniego stulecia wydarzyły się dwa wielkie kryzysy gospodarcze o zasięgu globalnym: Wielka Depresja zapoczątkowana w 1929 r. i Wielka Recesja, która wybuchła w 2007 r. ${ }^{1}$ Wielki kryzys lat 30-tych XX wieku był określany bardziej jako największy kryzys gospodarczy, kryzys lat 2007-2010 uznany został jako największy kryzys finansowy. W obydwu przypadkach nastapiło załamanie w sektorze bankowym i powiązanych $\mathrm{z}$ nim instytucjach finansowych. U podstaw aktualnego kryzysu finansowego można wskazać wiele nieprawidłowości, które narastały w sektorze bankowym wielu krajów, zwłaszcza w USA. Wśród najważniejszych wymienia się nadmierną akcję kredytową banków oraz towarzyszącą jej niewłaściwą ocenę ryzyka, w tym ryzyka związanego $\mathrm{z}$ procesem sekurytyzacji. ${ }^{2}$ Banki kreując nowy pieniądz

\footnotetext{
1 Iwanicz-Drozdowska M. Restrukturyzacja banków Unii Europejskiej w czasie globalnego kryzysu finansowego, Oficyna Wydawnicza SGH, Warszawa 2015, s 21

${ }^{2}$ Kumhof M, J. Zoltan: The Truth about Banks FD Finance and Development. A Quarterly Publication of the International Monetary Fund March 2016, Volume 53 - Number 1, s. 50-53
} 
kredytowy nie były zdolne zagwarantować wartości i stabilności zdeponowanym środkom finansowym i powiązanym z nimi inwestycjom. Niewystarczające regulacje systemów bankowych i finansowych nie były w stanie zatrzymać zjawisk kryzysowych i uniknąć ich skutków zarówno w jednym jak i w drugim kryzysie. Wyjaśnianie przyczyn i skutków oraz strategii wyjścia $\mathrm{z}$ recesji lat 2007-2010 jest aktualnie postrzegane nieco inaczej niż czyniły to tradycyjne teorie neoklasyczne.

Gospodarka Stanów Zjednoczonych, w której ujawnił się kryzys finansowy w 2007 r., jak i gospodarki innych krajów świata, na które kryzys szybko się rozprzestrzenił, nie były przygotowane na gwałtowne i głębokie załamanie. Na Wielką Recesję 2008 r. nie była przygotowana zarówno teoria ekonomii oraz krajowe i międzynarodowe instytucje kreujące politykę gospodarcza i finansową. W działaniach antykryzysowych nie wykorzystano też $\mathrm{w}$ zadowalający sposób historycznych doświadczeń z przebiegu Wielkiej Depresji z lat trzydziestych.

Kryzys dotknął także gospodarkę Polski, w tym system bankowy i finansowy. Chociaż nie przebiegał on z taką ostrością jak w najbardziej rozwiniętych krajach świata to jego skutki odczuły nie tylko banki $\mathrm{i}$ instytucje finansowe, miał wpływ także na przedsiębiorstwa, gospodarstwa domowe, budżety i finanse publiczne. Celem tego opracowania jest przedstawienie wpływu globalnego kryzysu gospodarczego na gospodarkę Polski oraz działań naprawczych i zapobiegawczych podejmowanych przez państwo i krajowe oraz międzynarodowe i wspólnotowe instytucje finansowe.

\section{Ogólny zarys kryzysu finansowego lat 2007-2010}

Kryzys finansowy ujawnił się krachem na rynku nieruchomości w Stanach Zjednoczonych w latach 2007-2008. ${ }^{3}$ Powodów i oznak powstania kryzysu można doszukiwać się jednak wcześniej. Iwanicz-Drozdowska wyróżnia trzy fale kryzysu finansowego, z których pierwsza miała miejsce w 2006 r., kiedy upadła pierwsza amerykańska firma brokerska Merit Financial Inc. ${ }^{4}$ W 2007 r. miały miejsce upadłości kolejnych instytucji brokerskich oraz innych instytucji finansowych i funduszy. W Europie pierwsza fala kryzysu przeszła stosunkowo łagodnie i dopiero upadek Lechman Brothers, który nastapił w drugiej fali kryzysu przyniósł istotne straty i utratę zaufania między uczestnikami rynku. Trzecia fala kryzysu ujawniła się w Europie w 2010 r. kiedy zaostrzyły się problemy finansowe Grecji. Według ekonomistów MFW w latach 20072011 wystapiło 11 przypadków systemowych kryzysów bankowych w krajach członkowskich Unii Europejskiej i dodatkowo w kilkunastu innych krajach świata. ${ }^{5}$

W Stanach Zjednoczonych, w których zrodził się kryzys od dawna funkcjonowały dwie instytucje powstałe po Wielksiej Depresji lat 30-tych - Federal National Mortgage Association (Fannie Mae) oraz utworzona w 1970 r. konkurencyjna Federal Home Loan Mortgage Corporation (Freddie Mac), które miały charakter instytucji sponsorowanych przez państwo chociaż faktycznie nie posiadały odpowiednich gwarancji rządowych. Duża skala prowadzonych operacji i powiązanie z

\footnotetext{
${ }^{3}$ Sławiński A., Przyczyny globalnego kryzysu bankowego (w:) Nauki społeczne wobec kryzysu na rynkach finansowych. Kolegium Ekonomiczno-Społeczne SGH, Warszawa 2008, s. 36-37

${ }^{4}$ Iwanicz-Drozdowska M., Restrukturyzacja banków op. Cit. s. 11

${ }^{5}$ Costa Navajas M., A. Thegeya, Financial Soundness Indicators and Banking Crises, IMF Working Papers 2013, No $13 / 263$ s. 28
} 
państwem stwarzało opinię, iż zapewniają one stabilność finansową na rynku nieruchomości. To przekonanie wynikało z wysokiej wiarygodności gospodarki USA. W takiej sytuacji należności kredytowe łatwo mogły być przekształcane w papiery wartościowe, co umożliwiało refinansowanie zaciągniętych kredytów mieszkaniowych. System działał sprawnie dopóki w 1999 r. nie zostały zlikwidowane kryteria pożądanej zdolności kredytowej. Wtedy to stworzono możliwość udostępniania kredytów osobom, które nie spełniały niezbędnych kryteriów zdolności kredytowej, w wyniku czego powstały tzw. kredyty ,subprime”, kredyty o wysokim natężeniu ryzyka. Proces sekurytyzacji, czyli transakcji, w wyniku których ryzyko kredytowe ulega podziałowi na transze, spowodowało zwiększenie ilości aktywów, które były objęte instrumentami pochodnymi. Zwiększało to lawinowo wartość kontraktów i innych instrumentów pochodnych. Zwiększała się aktywność i efektywność funkcjonowania rynków lecz jednocześnie instytucje finansowe stały się bardziej podatne na szoki finansowe. ${ }^{6}$ Zwiększenie akcji kredytowej banków, przenoszenie ryzyka na nabywców instrumentów pochodnych, i trudności $\mathrm{w}$ ocenie rzeczywistego charakteru ryzyka to bezpośrednie przyczyny napędzania mechanizmu kryzysowego. Nie były one także dostrzegane przez instytucje ratingowe, które nie przekazały sygnałów ostrzegawczych przed kryzysem.

\section{Przyczyny kryzysu finansowego}

Przyczyn kryzysu należy upatrywać $\mathrm{w}^{7}$ : zjawiskach, które były skutkiem ekspansywnej polityki monetarnej Rezerwy Federalnej Stanów Zjednoczonych; braku efektywności w tworzeniu ładu instytucjonalnego na silnie zglobalizowanym rynku finansowym; defektach rynku, będących wynikiem wprowadzenia innowacyjnych produktów finansowych, za którymi nie nadążały odpowiednie rozwiązania regulacyjne ${ }^{8}$, ponieważ w tym okresie obowiązywał model nadzoru opierający się na samoregulacji rynków finansowych. ${ }^{9}$ Punktem zwrotnym w rozwoju kryzysu był upadek Lehman Brothers trzeciego, największego banku inwestycyjnego w USA, który nastapił w połowie września 2008 r. Posiadał on zbyt wysoką liczbę aktywów toksycznych w swoim bilansie i odnotował ogromne straty finansowe $\mathrm{z}$ ich tytułu. Bank nie uzyskał spodziewanej pomocy rządowej, co było ogromnym szokiem dla uczestników rynku finansowego. Wiele instytucji finansowych traciło płynność finansową w związku z wybuchem paniki wśród klientów zagrożonych upadkiem banków, którzy chcieli jak najszybciej odzyskać swoje wkłady finansowe. Wzbudziło to nieufność na rynku, co niemal doprowadziło do zablokowania funkcjonowania rynków: kredytowego oraz międzybankowego. Banki uświadomiły sobie przejściowo pasywną rolę rządu w likwidowaniu skutków kryzysu, a więc obawiając się niewypłacalności partnerów finansowych, zaprzestały udzielać kredytów oraz pożyczek instytucjom finansowym.

\footnotetext{
${ }^{6}$ Nieborak T., Globalny kryzys finansowy, istota, przyczyny, konsekwencje. Ruch Prawniczy, Ekonomiczny i Socjologiczny, Nr 42010

${ }^{7}$ Falkowski. K, , Teichmann. E (red.), Państwa battyckie i Europy Wschodniej. Reakcja na światowy kryzys gospodarczy i regionalny kryzys gazowy, SGH, Warszawa, 2010, s.50-55.

${ }^{8}$ Wojtyna. A (red), Kryzys finansowy i jego skutki dla krajów na średnim poziomie rozwoju, PWE, Warszawa, 2011, s.180.

${ }^{9}$ Konopczak M., Sieradzki R., Wiernicki M., Kryzys na światowych rynkach finansowych - wplyw na rynek finansowy w Polsce oraz implikacje dla sektora realnego, „Bank i Kredyt”, nr 6, 2010.
} 
Zamrożenie rynku finansowego, poskutkowało powstaniem krytycznej sytuacji w wielu innych bankach. Krach powstały na rynku finansowym szybko przeniósł się na gospodarkę realną, pogarszając sytuację gospodarstw domowych i przedsiębiorstw. Kryzys doprowadził do spowolnienia gospodarczego w USA. Podejmowano programy pomocy dla sektora finansowego, m.in. przez wykup toksycznych aktywów, lecz nie były one w stanie zatrzymać fali kryzysu. Kryzys rozprzestrzenił się na inne kraje świata i zakłócił funkcjonowanie gospodarki światowej. W pierwszej kolejności dotknął sektor bankowy oraz ubezpieczeniowy, ponieważ były one najbardziej zaangażowane w toksyczne aktywa, oparte na kredytach subprime. W następstwie kryzysu gospodarki światowe pogrążyły się w recesji, co doskonale pokazuje znaczący spadek światowego PKB, który w roku 2009 wykazał wartość mniejszą o -1,92 punktu w stosunku do roku $2008^{10}$. Kryzys ujawnił się $\mathrm{z}$ różna siłą i przyniósł różne skutki w wysokorozwiniętych gospodarkach kapitalistycznych, gospodarkach wschodzących i w krajach rozwijających się. Rozprzestrzenianie się kryzysu szybko wpłynęło na spadek aktywności gospodarczej na arenie międzynarodowej a jego konsekwencją było pogrążenie się gospodarki światowej w recesji już w I kwartale 2009 r. Miało to związek z dwoma zjawiskami: spadkiem światowego popytu, określanego jako szok popytowy oraz ograniczeniami w dostępie do krótkoterminowego finansowania. ${ }^{11}$

Kryzys najbardziej dotkliwie odczuły kraje wysokorozwinięte, ponieważ miały większy dostęp do instrumentów, których rynek załamał się w dobie kryzysu. Ujawniło się to w ogromnym spadku międzynarodowej wymiany towarowej czy też produkcji już od IV kwartału 2008 roku. ${ }^{12}$ Instytucje finansowe w gospodarkach wschodzących, do których należy m.in. Polska, nie odczuły tak bardzo bezpośrednich strat $\mathrm{z}$ tytułu inwestycji w instrumenty pochodne, w związku niewielką ich popularnością, a także dostępnością. Gospodarki krajów wysoko rozwiniętych oraz krajów wschodzących, odczuły skutki kryzysu ze względu na:

- spadek popytu zwłaszcza na rynkach finansowych w krajach wysoko rozwiniętych, co doprowadziło do załamania światowego eksportu;

- wstrząsy na rynkach finansowych oraz walutowych, które to spowodowały gwałtowne zmiany kursów walutowych, szczególnie w krajach wschodzących oraz wycofanie kapitału przez instytucje finansowe, które funkcjonowały na rynku międzynarodowym i chciały zrekompensować straty. ${ }^{13}$

Nastapiło znaczne zmniejszenie się obrotów handlowych w skali międzynarodowej. Od września 2008 roku do lutego 2009 roku, wymiana towarowa zmniejszyła się o ok. 17\%. Na początku roku 2009, odnotowano spadek wartości eksportu o więcej niż 5\% w ujęciu kwartalnym w ponad 90\% państw świata, a dla prawie $15 \%$ państw spadek wynosił ponad $20 \%$. W 2009 roku, wartość eksportu spadła o prawie $11 \%$. Spadek wymiany handlowej był znacznie wyższy niż spadek produkcji

\footnotetext{
${ }^{10}$ Rosati D. Przyczyny i mechanizm kryzysu finansowego w USA w latach 2007-2009 [w] G. Kołodko (red.) Globalizacja, kryzys i co dalej, Poltext Warszawa 2009

${ }^{11}$ Czekaj J., Wplyw Światowego kryzysu gospodarczego na polska gospodarkę, [w:] Kołodko. G (red.), Globalizacja, kryzys i co dalej?, Poltext Sp. z o.o., Warszawa, 2010, s.195

${ }_{12}$ Global Financial Stability Report, 2010, International Monetary Fund, WashingtonDCApril. Dostępny w Internecie: https://www.imf.org/external/pubs/ft/gfsr/ [online: 20.02.2015r.]

${ }^{13}$ Czekaj J., Wplyw Światowego kryzysu gospodarczego..., s.196
} 
światowej, która to w konsekwencji kryzysu w roku 2009 w krajach rozwiniętych spadła o $3,4 \%$.

Następnym negatywnym skutkiem kryzysu w sferze realnej, było ograniczanie wydatków inwestycyjnych wśród przedsiębiorstw, zarówno jeśli chodzi o inwestycje w środki trwałe, jak również w zapasy. Do najważniejszych przyczyn spowolnienia inwestycji wśród przedsiębiorstw należały: załamanie popytu, niepewna sytuacja gospodarki światowej w przyszłości; małe wykorzystanie mocy produkcyjnych; spadek marży zysku; zaostrzone warunki finansowania działalności. Dla przykładu, w Europie, inwestycje w środki trwałe zmniejszyły się w 2009 roku w porównaniu z rokiem 2008 o prawie $14 \%$.

Analiza stopy inwestycji w krajach strefy euro pozwala zauważyć, że tendencja spadkowa, która zaczęła się wraz z czwartym kwartałem 2008 roku, zakończyła się w drugiej połowie 2010. Wynikało to $\mathrm{z}$ restrukturyzacji bilansów przedsiębiorstw i powolnego wzrostu wykorzystania mocy produkcyjnych, a także z faktu, że droga do przywrócenia skłonności przedsiębiorców do inwestowania jest trudna i trwa z natury przez długi czas.

Oprócz wyżej opisanych następstw wybuchu kryzysu finansowego można wymienić jeszcze szereg innych, a w tym: ${ }^{14}$

- Ogłoszenie upadłości lub przejęć wielu instytucji finansowych oraz znacjonalizowanie tych, którym groziło bankructwo;

- Załamanie rynków papierów wartościowych w USA, Wielkiej Brytanii, krajach strefy euro oraz krajach azjatyckich;

- Straty poniesione przez fundusze inwestycyjne oraz emerytalne, które inwestowały głównie na rynkach papierów wartościowych.

- Wzrost wydatków rządowych na dofinansowanie banków i innych instytucji finansowych, ustabilizowanie rynków finansowych oraz inne działania interwencyjne.

- Zwiększenie deficytu budżetowego i długu publicznego, zwłaszcza w Japonii, strefie euro i USA. ${ }^{15}$

Współczesny kryzys finansowy z całą pewnością uwidocznił fakt, że błędy popełniane $\mathrm{w}$ sferze finansowej zagrażają poprawnemu funkcjonowaniu sfery realnej, a konsekwencje niewłaściwych wyborów finansistów dotykają nie tylko instytucji finansowych, ale istotnie wpływają na sytuację gospodarstw domowych, przedsiębiorstw i instytucji samorządowych.

Pozytywnym aspektem kryzysu było wprowadzenie zmian, których szansa realizacji w ,normalnych” warunkach byłaby znikoma.

\section{Makroekonomiczna sytuacja Polski w latach 2007-2013}

Makroekonomiczna sytuacja w Polsce od lat jest determinowana wydarzeniami, które mają miejsce na światowych rynkach finansowych. Zachodzące zmiany mają wpływ zarówno na ogólny stan gospodarki, jak i poszczególne jej sektory, w tym rynek

14 Adamczyk. M, Współczesny kryzys finansowy - przyczyny i konsekwencje dla gospodarki światowej. Dostępny w Internecie: http://ekonom.ug.edu.pl/web/download.php?OpenFile=930 [online:31.03.2015r.]

${ }^{15}$ Nawrot W., Globalny kryzys finansowy XXI wieku Przyczyny, przebieg, skutki, prognozy, Wyd.CeDeWu, Warszawa, s.83-120. 
finansowy, giełdowy i sferę realną. Przyczyną wzajemnej zależności krajów świata, jest postępująca globalizacja, która przyniosła duże korzyści $w$ sferze handlu międzynarodowego jak i międzynarodowych przepływów kapitałowych. Polska uczestnicząc w procesach globalnych, narażona jest też na globalny kryzys finansowy.

Kryzys początkowo omijał gospodarkę Polski. Głównymi zagrożeniami, na jakie wskazywano, były: niebezpieczna zależność polskiego złotego od spekulacyjnych inwestycji krótkoterminowych; wysokie zadłużenie państwa; duży udział importu w produkcji.

Następnie pojawiły się jednak inne czynniki, które spowodowały przeniesienie kryzysu finansowego do Polski, a mianowicie: ograniczona przez banki akcja kredytowa oraz atak spekulantów na walutę polską i znaczne obniżenie jej wartości. Niemniej jednak na tle innych państw europejskich sytuacja panująca w Polsce była oceniana pozytywnie.

Najważniejszy miernik ogólnego stanu gospodarki kraju, jakim jest PKB w czasie wybuchu kryzysu finansowego kształtował się korzystnie (tab. 1).

Tabela 1. Zmiany PKB i popytu krajowego w latach 2007-2013 w \%

\begin{tabular}{|c|c|c|c|c|c|c|c|}
\hline Wyszczególnienie & $\mathbf{2 0 0 7}$ & $\mathbf{2 0 0 8}$ & $\mathbf{2 0 0 9}$ & $\mathbf{2 0 1 0}$ & $\mathbf{2 0 1 1}$ & $\mathbf{2 0 1 2}$ & $\mathbf{2 0 1 3}$ \\
\hline PKB & 6,7 & 4,9 & 1,8 & 3,9 & 4,0 & 2,0 & 1,2 \\
\hline Popyt krajowy & 8,4 & 5,6 & $-1,1$ & 4,6 & 3,6 & 2,3 & 1,2 \\
\hline
\end{tabular}

Źródło: GUS Rachunki kwartalne PKB w latach 2007-2013. Dostępny w Internecie: stat.gov.pl, [online.10.04.2015r.]

Na wysoką wartość PKB w latach 2007-2008, wpłynął m.in. popyt krajowy, który umacniał się w związku z rozwojem inwestycji, do czego przyczyniły się napływ do Polski kapitału, który przybrał formę bezpośrednich inwestycji zagranicznych oraz wzrost wykorzystania funduszy z UE. Ważnym czynnikiem był też wzrost konsumpcji, który wystąpił w wyniku poprawy sytuacji panującej na rynku pracy i spadku stopy bezrobocia, wzrostu wartości wynagrodzeń, wzrostu zadłużenia gospodarstw domowych, transferu środków unijnych dla rolników oraz transferu dochodów z pracy poza granicami kraju.

Rok 2009 przyniósł ze sobą głębokie spowolnienie gospodarki światowej. Wśród państw Europy tylko Polska zdołała utrzymać dodatnią dynamikę PKB. Przyczyniły się do tego głównie eksport, inwestycje publiczne i konsumpcja prywatna. Z kolei spadek popytu krajowego w 2009 roku był efektem pogorszenia się sytuacji na rynku pracy. ${ }^{16} \mathrm{~W} 2010 \mathrm{r}$. nastapiła niewielka, ale widoczna poprawa światowej sytuacji makroekonomicznej. Spośród 27 państw należących do UE - 22 kraje wykazały dodatnie tempo wzrostu PKB. Polska znajdowała się w czołówce, nieznacznie ustępując tylko Słowacji oraz Szwecji. Poprawa sytuacji gospodarczej panującej w Polsce w roku 2010 roku oraz jej kontynuacja w kolejnych latach była efektem ożywienia u jej partnerów handlowych. Popyt zewnętrzny doprowadził do pobudzenia produkcji przemysłowej i poprawy sytuacji panującej na rynku pracy.

Światowy kryzys finansowy wywarł jednak silny wpływ na finanse publiczne w Polsce, zarówno na poziomie budżetu centralnego jak i budżetów samorządowych. ${ }^{17}$

\footnotetext{
${ }^{16}$ Miszkin F.S., Ekonomika pieniqdza, bankowości i rynków finansowych, PWN, Warszawa 2002, s.349.

${ }^{17}$ Satoła Ł.. Kryzys finansów publicznych z perspektywy społeczności lokalnej. Roczniki Naukowe SERiA Tom XIV zeszyt 4, s. 104-109.
} 
Efekty kryzysu finansowego na szczeblu makroekonomicznym ujawniają się zwiększeniem deficytu budżetowego i narastaniem długu publicznego i wynikającymi z tego wzrastającymi kosztami obsługi tego długu oraz utratą zaufania na rynkach finansowych. Dochody budżetu państwa wynoszące 274,4 mld zł w 2009 r. spadły do 250,3 mld zł w 2010 r., wydatki zaś wzrosły odpowiednio z 277,9 mld zł do 298,2 mld zł roku 2009 by zmniejszyć się nieznacznie do poziomu 294,9 mld zł w 2010 r. Deficyt budżetowy wzrósł gwałtownie z około 24 mld w latach 2008-2009 do 44,6 mld w 2010 r. i niewiele mniejszego poziomu 40,2 mld w 2011 r. Znaczący wzrost nierównowagi budżetowej wywołał konieczność podejmowania działań zaradczych w sferze finansów publicznych.

\section{Sytuacja polskich przedsiębiorstw w latach 2007 - 2010}

Polskie przedsiębiorstwa silniej odczuwały długotrwałe skutki kryzysu finansowego pomimo tego, że jego krótkotrwałe efekty dotknęły kraj znacznie słabiej niż inne państwa Unii. Wynika to $\mathrm{z}$ kilku przyczyn, a mianowicie gospodarka Polski nacechowana była licznymi słabościami, które mają charakter strukturalny; program inwestycyjny gospodarki polskiej był mocno uzależniony od importu kapitału, pochodzącego głównie z państw Europy Zachodniej, do którego dostęp jest utrudniony; polski sektor bankowy był w dużym stopniu związany ze światowym systemem bankowym; polskie przedsiębiorstwa uzależnione były od eksportu na rynki zachodnioeuropejskie, a długookresowa, słaba koniunktura na tych rynkach prowadziłs do utrudnienia rozwoju polskich firm, co przyniosło za sobą konieczność wprowadzenia radykalnych restrukturyzacji; Polska oferowała przedsiębiorstwom trudne warunki prowadzenia działalności, na co miały wpływ przede wszystkim: obciążenia podatkowe i bariery biurokratyczne. ${ }^{18}$

Jednym z negatywnych skutków kryzysu, który dotknął przedsiębiorstwa, było osłabienie możliwości finansowania ich działalności operacyjnej i inwestycyjnej. W związku ze spadkiem zaufania na rynku finansowym oraz pogorszeniem kondycji finansowej banków, zmniejszyły się możliwości dostępu do kredytów i wzrosły koszty ich zaciagnięcia. Dotknęło to szczególnie małe oraz średnie firmy. Duże przedsiębiorstwa miały $\mathrm{z}$ kolei problem $\mathrm{z}$ uzyskaniem kredytu konsorcjalnego, udzielanego celem finansowania dużych projektów przez grupę banków. Trudności, które dotknęły przedsiębiorstwa szybko przeniosły się z na rynek pracy, co skutkowało redukcją zatrudnienia i narastaniem obaw o utratę pracy. W następstwie takich wydarzeń zmniejszył się popyt konsumpcyjny: w marcu 2009 roku odnotowano spadek sprzedaży detalicznej o ok. 1,8\% w ujęciu rocznym. Utrudniony dostęp do finansowania powstałych zatorów płatniczych spowodował pogorszenie sytuacji firm i upadłości wielu z nich. W pierwszym kwartale 2009 r. odnotowano 105 upadłości, co oznaczało wzrost o $11 \% \mathrm{w}$ stosunku do roku poprzedniego, gdzie w tym samym czasie było ich $95 .{ }^{19}$ Największą liczbę upadłości zarejestrowano w województwie mazowieckim. W porównaniu z rokiem 2008, najbardziej wzrosła liczba upadłości w województwie

\footnotetext{
${ }^{18}$ Rok kryzysu. Co dalej? Wyzwania stojace przed spótkami, PricewaterhouseCoopers, Warszawa, 2009. Dostępny w Internecie: https://www.pwc.pl/ [online: 24.04.2015r.]

${ }^{19}$ Ministerstwo Finansów, Informacja kwartalna o sytuacji makroekonomicznej i stanie finansów publicznych, Dostępny w Internecie: www.wneiz.pl/nauka [online: 24.04.2015r.]
} 
dolnośląskim, gdzie znajdowało się najwięcej przedsiębiorstw z branży motoryzacyjnej oraz transportowej, w województwie warmińsko-mazurskim, gdzie znajdują się ośrodki przemysłu meblowego, a także w województwie podkarpackim - gdzie doszło do załamania handlu przygranicznego. Najwięcej upadłości ogłoszono w firmach z sektora produkcyjnego, jednak wystąiły one prawie w każdym sektorze działalności ${ }^{20}$.

Tabela 2 przedstawia ogólną kondycję polskich firm zatrudniających powyżej 50 pracowników w czasie kryzysu w latach 2007-2010. Przedsiębiorstwa duże oraz średnie należą do sektora, w którego działalność jest wpisana współpraca z przedsiębiorstwami zagranicznymi, w związku z czym są zdecydowanie bardziej narażone na następstwa kryzysu.

Tabela 2. Wybrane efekty uzyskane przez polskie przedsiębiorstwa zatrudniające powyżej 50 osób w latach 2007-2010 w mln zł.

\begin{tabular}{|l|c|c|c|c|}
\hline Wyszczególnienie & $\mathbf{2 0 0 7}$ & $\mathbf{2 0 0 8}$ & $\mathbf{2 0 0 9}$ & $\mathbf{2 0 1 0}$ \\
\hline Przychody z prowadzenia działalności & 1716630 & 1905752 & 1932987 & 2029731 \\
\hline $\begin{array}{l}\text { Koszty uzyskania przychodów z } \\
\text { prowadzenia działalności }\end{array}$ & 1611822 & 1825886 & 1837000 & 1922052 \\
\hline $\begin{array}{l}\text { Wynik na prowadzonej działalności } \\
\text { gospodarczej }\end{array}$ & 104808 & 79866 & 95987 & 107679 \\
\hline Zysk netto & 95473 & 85279 & 97535 & 103164 \\
\hline Strata netto & 9224 & 22283 & 18670 & 13718 \\
\hline
\end{tabular}

Źródto: GUS. Raport o stanie sektora malych i średnich przedsiębiorstw 2007-2010. Dostęny w Internecie: www.pi.gov.pl/ [online: 25.04.2015r.]

Pierwsze oznaki kryzysu finansowego badane firmy odczuły w 2008 roku, kiedy to zanotowały wzrost wielkości straty netto o ok. $242 \% \mathrm{w}$ porównaniu do roku poprzedniego, przy jednoczesnym spadku wygenerowanego zysku netto o prawie $11 \% \mathrm{i}$ wzroście pozostałych wskaźników. W roku 2009 średnie i duże firmy krajowe, nadal odczuwały następstwa kryzysu, ponieważ państwa Europy Zachodniej, będące ich głównymi partnerami handlowymi, odnotowały ujemny wzrost gospodarczy. Niskie było także tempo wzrostu popytu krajowego, co niewątpliwie miało wpływ na sytuację przedsiębiorstw. Pomimo takiego obrotu wydarzeń, przychody uzyskane z całokształtu działalności w 2009 roku wzrosły o 1\% w porównaniu z 2008r. Wzrost kosztów ich uzyskania zwiększył się niewiele, bo o $0,6 \%$ - co spowodowało poprawę wyniku na prowadzonej działalności gospodarczej. Wysokość straty netto w stosunku do 2008 roku zmniejszyła się o ponad $16 \%$. Oznacza to, że załamanie było krótkotrwałe i kondycja przedsiębiorstw zatrudniających powyżej 50 osób zaczęła się poprawiać.

\section{Sytuacja na Giełdzie Papierów Wartościowych w Warszawie}

Załamanie się rynku nieruchomości w USA spowodowało lawinę wydarzeń. Skutki kryzysu dotknęły sektor bankowy na całym świecie. Banki posiadały wiele papierów

\footnotetext{
${ }^{20}$ Orłowski W., Pasternak R., Flaht K., Szubert D., Procesy inwestycyjne i strategie przedsiębiorstw w czasach kryzysu, Projekt wspólfinansowany przez Unię Europejskq w ramach Europejskiego Funduszu Społecznego, Polska Agencja Rozwoju Przedsiębiorczości, Warszawa, 2010. Dostępny w Internecie: bip.parp.gov.pl/ [online: 25.04.2015r.]
} 
dłużnych, które były zabezpieczone złymi kredytami hipotecznymi. Wraz ze spadkiem cen nieruchomości, spadały ceny papierów wartościowych. W czerwcu i w sierpniu 2007 roku spadek indeksów giełdowych na czołowych giełdach świata przeniósł się na rynek polski. Napływ negatywnych informacji z zewnątrz odbił się spadkiem indeksów giełdowych, na co z niepokojem reagowali inwestorzy. GPW w Warszawie najsilniej odczuła piętno kryzysu w 2008 roku, co potwierdzają stopy zwrotu najważniejszych indeksów giełdowych (tabela 3).

Tabela 3. Kształtowanie się stóp zwrotu wybranych indeksów Warszawskiej Giełdy Papierów Wartościowych w latach 2007-2010, w czasie kiedy giełda najbardziej odczuła skutki kryzysu

\begin{tabular}{|l|l|l|l|l|}
\hline \multicolumn{1}{|c|}{ Indeksy } & \multicolumn{1}{c|}{$\mathbf{2 0 0 7}$} & $\mathbf{2 0 0 8}$ & \multicolumn{1}{c|}{$\mathbf{2 0 0 9}$} & $\mathbf{2 0 1 0}$ \\
\hline WIG20 (\%) & 5,19 & $-48,21$ & 33,47 & 14,88 \\
\hline WIG-PL (\%) & 9,23 & $-50,62$ & 44,93 & 18,70 \\
\hline mWIG40 (\%) & 7,90 & $-62,48$ & 55,24 & 19,57 \\
\hline sWIG80 (\%) & 25,17 & $-56,95$ & 61,85 & 10,18 \\
\hline
\end{tabular}

Źródła. Podstawowe statystyki GPW. Dostęp w Internecie:

http://www.gpw.pl/analizy_i_statystyki_pelna_wersja [online: 30.04.2015r.]

Pogorszenie sytuacji na GPW było widoczne już w 2007 roku, kiedy to wszystkie indeksy zanotowały niskie stopy zwrotu. do załamania sytuacji panującej na rynku kapitałowym w Polsce doszło w okresie kulminacji wielkiej recesji globalnej w 2008 roku. Dane z roku 2009 ukazują, że w okresie spowolnienia polskiej gospodarki, najlepiej radziły sobie spółki małe, których stopa zwrotu wynosiła $61,85 \%$ i średnie, których stopa zwrotu $\mathrm{z}$ inwestycji wyniosła $55,24 \%$. Poprawa nie miała jednak charakteru trwałego. W roku 2010 stopy zwrotu indeksów Warszawskiej GPW w dalszym ciagu wykazywały wartość dodatnią, ale w stosunku do roku poprzedniego, odnotowano tendencję spadkową. ${ }^{21}$

\section{Skutki kryzysu finansowego w sektorze gospodarstw domowych}

W przypadku polskiej gospodarki najtrudniejsza sytuacja spowodowana kryzysem finansowym w sektorze gospodarstw domowych została odnotowana na przełomie lat 2008 - 2009. Gospodarstwa domowe spotkały się najpierw z zaostrzeniem polityki kredytowej banków. Taką sytuację potwierdziły badania ankietowe przeprowadzone przez NBP w bankach.

Sytuacja panująca na rynku finansowym, a także pogarszająca się koniunktura gospodarcza, mają negatywny wpływ na możliwość uzyskania oraz koszt obsługi kredytu. Z ankiety przeprowadzonej przez NBP wynikało, że już w IV kwartale roku 2008, banki zaostrzyły prowadzoną politykę kredytową. Stało się tak zarówno względem udzielanych przez nie kredytów mieszkaniowych, jak i kredytów konsumpcyjnych. Nieco powyżej $85 \%$ ankietowanych banków zaostrzyło wymagania dotyczące udzielania kredytów mieszkaniowych, z czego $20 \%$ zaostrzyło je znacznie. ${ }^{22}$ Należy podkreślić, że

\footnotetext{
${ }^{21}$ Gruszczyńska-Brożbar. E., Funkcjonowanie GPW w Warszawie w świetle światowego kryzysu finansowego, w: Finanse 2009 - Teoria i praktyka. Rynki finansowe i ubezpieczenia, Zeszyty Naukowe $\mathrm{nr}$ 550, Ekonomiczne Problemy Usług nr 40, Wydawnictwo Naukowe Uniwersytetu Szczecińskiego, Szczecin, 2009.

${ }^{22}$ Sytuacja na rynku kredytowym. Wyniki ankiety dla przewodniczacych komitetów kredytowych.I kwartat 2009, Departament Systemu Finansowego NBP, Warszawa, 2009, http://www.nbp.pl [dostęp: 15.05.2015r.].
} 
żaden $\mathrm{z}$ badanych banków nie złagodził wówczas kryteriów udzielania kredytów na zakup mieszkania, a wymogi dotyczące ich udzielania zaostrzyły nawet te banki, które deklarowały wcześniej chęć złagodzenie bądź brak zaostrzenia polityki kredytowej. Postanowienia banków miały charakter nieoczekiwany dla otoczenia, a wynikały głównie ze zmian, które nastąpiły na rynku międzybankowym. Badanie przeprowadzone przez NBP pokazało, że zaostrzono każdy $\mathrm{z}$ warunków udzielenia kredytu mieszkaniowego, tj: prawie 75\% banków zwiększyło marże kredytową; około $90 \%$ banków podniosło kwotę wymaganego wkładu własnego; ponad 40\% banków zwiększyło pozaodsetkowe koszty kredytu; prawie $20 \%$ banków zmniejszyło maksymalny okres kredytowania; około $75 \%$ banków zaostrzyło nieuwzględnione w przeprowadzonym badaniu wymagania dotyczące udzielenia kredytu mieszkaniowego. Zaostrzenia dotyczyły m.in. obliczania zdolności kredytowej, gromadzenia dokumentów potwierdzających posiadany przez kredytobiorcę dochód oraz zasad wyceny nieruchomości.

Z ankiety NBP wynikało także, że zdecydowana większość banków zaostrzyła także wymogi dotyczące udzielania kredytu mieszkaniowego denominowanego we frankach szwajcarskich. Do najbardziej istotnych przyczyn, przez które zaostrzono politykę kredytową dotyczącą udzielania kredytów mieszkaniowych zaliczono: ryzyko, które było związane z sytuacją gospodarczą Polski; prognozy, które dotyczyły sytuacji na rynku mieszkaniowym; niekorzystną ocenę obecnej i prognozowanej własnej sytuacji kapitałowej banków.

Pierwszym negatywnym skutkiem zaostrzenia prowadzonej przez banki polityki kredytowej był spadek popytu na kredyty mieszkaniowe. Działo się tak, mimo tego, że ceny nieruchomości spadały. Drugim powodem, przez który ludność rezygnowała $\mathrm{z}$ zaciągania kredytów, była niepewna sytuacja panująca na rynku pracy. Warto podkreślić, że kryzys spowodował obniżenie presji inflacyjnej. Stanowiło to przesłankę umożliwiającą Radzie Polityki Pieniężnej dokonanie obniżki stóp procentowych w kraju. Stopy referencyjne rosły od kwietnia 2007 do czerwca 2008 r. a następnie zaczęły spadać. W wyniku sześciu następujących po sobie obniżek, stopa referencyjna, zmalała w okresie od listopada 2008 roku do czerwca 2009 roku z 6\% do bardzo niskiego poziomu 3,50\%, co stanowiło jej zmniejszenie o prawie $42 \% \mathrm{w}$ przeciągu 8 miesięcy. Wynikiem decyzji podjętej przez Radę Polityki Pieniężnej stopa WIBOR 3M24, od której zależne jest oprocentowanie wielu kredytów mieszkaniowych udzielonych w polskich złotych, odnotowała spadek w tym samym okresie z ponad 6,6\% do, około $4,15 \%$, co stanowiło prawie $38 \%$ zmniejszenie. W związku z zachodzącymi zmianami, oprocentowanie udzielonych kredytów na zakup mieszkań w złotych uległo obiniżeniu o prawie 2,5 pkt procentowych. Oznacza to, że przy zawarciu umowy o kredyt w wysokości trzystu tysięcy złotych, zaciągniętego na trzydzieści lat i spłacanego w ratach miesięcznych, powodowało zmniejszenie raty o prawie pięćset złotych.

Badanie przeprowadzone przez NBP wykazało, że zaostrzenie polityki kredytowej banków nastąpiło również w przypadku kredytów konsumpcyjnych. Niemniej jednak zmiana wymogów dotycząca udzielania tego rodzaju kredytów była zgodna $\mathrm{z}$ przewidywaniami. Zaostrzenie polityki dotyczącej udzielania kredytów konsumpcyjnych polegało na: podniesieniu marż przez około 40\% banków; podwyższeniu pozaodsetkowych kosztów kredytów przez prawie 13\% banków; 
zwiększeniu wymagań dotyczących zabezpieczeń kredytu przez 22\% banków; zmniejszeniu maksymalnych kwot kredytu przez około 15\% banków.

Wśród najważniejszych przyczyn zaostrzenia polityki kredytowej w sferze kredytów konsumpcyjnych można wymienić: ryzyko związane z niepewną sytuacją gospodarczą kraju; pogorszenie własnej sytuacji kapitałowej w badanych bankach; pogorszenie się jakości portfela kredytowego.

Równolegle ze wzrostem utrudnień dostępu do kredytów mieszkaniowych i konsumpcyjnych nastapił wzrost zadłużenia gospodarstw domowych i kosztów jego obsługi. W latach 2007-2008, w czasie trwania pomyślnej koniunktury gospodarczej, kiedy malała stopa bezrobocia oraz rosły płace realne, można było zauważyć rosnące tempo wzrostu zadłużenia gospodarstw domowych (tab. 4).

Tabela 4. Zmiany wartości kredytów udzielanych gospodarstwom domowym we wczesnych latach kryzysu 2007-2008

\begin{tabular}{|l|c|c|c|}
\hline \multicolumn{1}{|c|}{ Kwartał } & $\begin{array}{c}\text { Wartość nominalna } \\
\text { kredytów udzielonych } \\
\text { w mld zł na koniec } \\
\text { kwartału }\end{array}$ & $\begin{array}{c}\text { Wartość kredytów } \\
\text { mieszkaniowych } \\
\text { udzielonych w polskich } \\
\text { złotych (w mld zł) }\end{array}$ & $\begin{array}{c}\text { Wartość kredytów } \\
\text { mieszkaniowych } \\
\text { udzielonych w walucie } \\
\text { obcej (w mld zł) }\end{array}$ \\
\hline I kwartał 2007 roku & 198455 & 32820 & 54314 \\
\hline II kwartał 2007 roku & 217065 & 39882 & 56871 \\
\hline III kwartał 2007 roku & 238638 & 46980 & 62648 \\
\hline IV kwartał 2007 roku & 254202 & 52600 & 65134 \\
\hline I kwartał 2008 roku & 273861 & 56214 & 74688 \\
\hline II kwartał 2008 roku & 292970 & 57660 & 96779 \\
\hline III kwartał 2008 roku & 319761 & 57651 & 134971 \\
\hline IV kwartał 2008 roku & \multicolumn{2}{|c|}{368 637 } & 5998 \\
\hline
\end{tabular}

Od marca 2007 roku do grudnia 2008 roku, zadłużenie gospodarstw domowych stopniowo wzrastało. W IV kwartale 2008 roku wzrosło o ponad $85 \%$ w stosunku do I kwartału roku 2007 i wyniosło 368 mld zł. Wysoki przyrost zadłużenia, nie był wynikiem tylko i wyłącznie akcji kredytowych przeprowadzanych przez banki. W związku z globalnym kryzysem na rynku finansowym osłabiła się wartość polskiego złotego w stosunku do walut światowych. Gwałtowne obniżenie wartości polskiego złotego przede wszystkim w stosunku do franka szwajcarskiego, spowodowało, że zadłużenie gospodarstw domowych z tytułu zaciągniętych kredytów mieszkaniowych w walucie obcej wzrosło w okresie od III kwartału 2008 roku do końca IV kwartału 2008 roku z prawie $97 \mathrm{mld}$ zł do ponad 134,9 mld zł, czyli ponad 48\%. Z racji na omawianą wcześniej zmianę nastawienia banków i zaostrzenie wymogów przyznawania kredytów mieszkaniowych, można przyjąć, że przyrost zadłużenia gospodarstw domowych wyniknął ze spadku wartości waluty. Wzrost kursu franka szwajcarskiego wobec polskiego złotego spowodował również wzrost raty kredytu. Warto jednak podkreślić, że w przypadku wielu osób, które zaciagnęły kredyt we franku szwajcarskim, niekorzystne skutki, które wyniknęły ze zmiany kursu walutowego, były rekompensowane, o wiele niższym niż w Polsce poziomem stóp procentowych w Szwajcarii. Problem zadłużenia 
gospodarstw domowych w wyniku zadłużenia we frankach szwajcarskich nie został rozwiązany a wynikające z niego trudności trwają dalej.

Kryzys spowodował istotne zmiany na rynku pracy. Gdy w roku 2008 kryzys dotarł do Polski sytuacja osób zatrudnionych była dobra, wg danych GUS wzrost ten w stosunku do roku 2007 wynosił 6,0\%. Stopa bezrobocia w stosunku do roku 2007 spadła o $2,87 \%$. Wzrastały również płace realne. Dobra passa nie trwała długo. W związku ze spadkiem popytu na produkty i usługi, pracodawcy zaczęli ciąć koszty w tym również koszty związane z zatrudnieniem pracowników. Stopa bezrobocia rejestrowanego od roku 2008 do końca roku 2009 wg danych podanych przez GUS wzrosła o 1,15\%. O ile w roku 2008 można było mówić o tendencji wzrostowej liczby osób pracujących o tyle od 2009 roku notuje się ich ciagły spadek, co wpływa na zwiększenie liczby osób bezrobotnych w kraju. Od 2008r do roku 2013, odnotowano 3,71\% wzrost liczby osób bezrobotnych, na co negatywny wpływ miały na pewno likwidacje i upadłości przedsiębiorstw w czasie kryzysu. W związku z cięciem kosztów spadały również miesięczne płace realne, tak więc osoby które zachowały etat, musiały pogodzić się z redukcją wynagrodzenia. Zmiany zachodzące na rynku pracy wywoływały wśród zatrudnionych obawę o utratę miejsca pracy, co mogło mieć wpływ na zmniejszenie skłonności do konsumpcji oraz zaciągania długoterminowych zobowiązań.

\section{Wpływ kryzysu finansowego na sytuację jednostek sektora publicznego}

Przedstawione wcześniej zjawiska ograniczania dochodów budżetu państwa, zwiększenie deficytu budżetowego oraz narastanie długu publicznego oddziaływały niekorzystnie także na finanse samorządów terytorialnych i wszystkich jednostek sektora publicznego. To oddziaływanie konkretyzowało się w ograniczaniu dochodów podmiotów publicznych, konieczności podnoszenia wydatków w celu minimalizacji negatywnych skutków kryzysu oraz poszukiwaniu sposobów przeciwdziałania trendom spadkowym i przeciwstawiania się atmosferze recesji i stagnacji w układach regionalnych i lokalnych.

Badania przeprowadzone w 2011 r. w pięciu województwach południowej Polski wykazały, że mieszkańcy miast i wsi reprezentujący społeczności lokalne dostrzegali negatywny wpływ kryzysu finansowego na kondycję finansów publicznych. ${ }^{23}$ Badania Satoły wykazują, że prawie $16 \%$ ankietowanych (228 respondentów) uznało kryzys finansowy za główny czynnik sprawczym pogorszenia finansów państwa i aż 83\% respondentów uznało, że kryzys finansowy wpłynął negatywnie na ich własną sytuację materialną, z czego prawie połowa stwierdziła, że ten wpływ jest znaczący. Badania przeprowadzone w skali krajowej przez CEBOS $^{24}$ również potwierdziły, że w $2008 \mathrm{r}$. negatywny wpływ kryzysu finansowego na sytuację materialna obywateli dostrzegało $18 \%$ Polaków, a w latach następnych odsetek ten wyraźnie się zwiększył.

\footnotetext{
${ }^{23}$ Satoła Ł. Kryzys finansów publicznych z perspektywy społeczności lokalnej. Roczniki Naukowe SERiA Tom XIV zeszyt 4, s. 104-109

${ }^{24}$ Centrum Badania Opinii Społecznej Reakcje na kryzys gospodarczy 2009. Komunikat z badań., Warszawa
} 
Ograniczenie deficytu budżetowego oznacza potrzebę cięcia wydatków publicznych zarówno na szczeblu centralnym jak i szczeblu samorządów terytorialnych. Zmniejszenie wydatków budzi kontrowersje i niezadowolenie tych, którzy tracą pewne przywileje i tych, którzy mają trudniejszy bądź ograniczony dostęp do usług społecznych. Mniej akceptowalnym sposobem równoważenia budżetów jest podnoszenie podatków i innych obciążeń fiskalnych. W rozwiązywaniu trudności $\mathrm{w}$ sferze finansów publicznych przydatne mogą też być działania o charakterze strukturalnym.

Zaprezentowana charakterystyka przebiegu i skutków kryzysu finansowego w Polsce wyraźnie świadczy o przesunięciu w czasie fazy cyklu koniunkturalnego. Rok 2007 w Polsce, gdy kryzys ujawnił się w USA i innych krajach, należy uznać za rok rozkwitu i dobrej koniunktury gospodarczej. Niestety światowe zjawiska związane z kryzysem szybko uderzyły w polską gospodarkę. Analiza następstw kryzysu dla polskiego handlu, inwestycji, produkcji czy zatrudnienia wskazuje jednak na to, że sfera realna $\mathrm{w}$ Polsce stosunkowo szybko wydostała się $\mathrm{z}$ zapaści. Wyjście $\mathrm{z}$ sytuacji kryzysowej w sferze finansów było opóźnione. W dalszym ciagu występuje zagrożenie wynikające z niestabilności rynków finansowych oraz osłabienia instytucji finansowych. Stabilny międzynarodowy system finansowy jest zatem warunkiem niezbędnym dla szybszego rozwoju polskiej gospodarki.

Należy stwierdzić, że wystapienie kryzysu finansowego w roku 2007, spowodowało szybką reakcję krajów świata w postaci przyjęcia planów naprawczych i wprowadzenia konkretnych działań $\mathrm{w}$ różnorakich dziedzinach, zarówno w sektorze finansowym jak i gospodarki realnej. Działania podjęte w zakresie zwalczania skutków kryzysu finansowego ułatwiły dostęp do środków finansowych szczególnie małym oraz średnim przedsiębiorstwom, które najbardziej odczuły ograniczenie dofinansowania. Podjęte środki zachęcały również do inwestycji, co miało spowodować pobudzenie popytu, a więc działanie nakierowane na walkę z kryzysem. Rozwiązania te z pewnością przyczyniły się do poprawy sytuacji gospodarczej.

\section{Program działań antykryzysowych w Polsce}

Program antykryzysowy $w$ Polsce był powiązany $\mathrm{z}$ działaniami Unii Europejskiej. Komisja Europejska w dniu 28 listopada 2008 roku, przedstawiła plan ratunkowy dla gospodarki. Działania naprawcze opierały się na dwóch filarach. Pierwszy zakładał: uruchomienie krótkoterminowych środków finansowych, aby zwiększyć popyt; utrzymanie dotychczas powstałych miejsc pracy, poprzez szkolenia i przekwalifikowanie pracowników; przywrócenie utraconego zaufania ludności do instytucji finansowych. ${ }^{25}$ Drugi filar opierał się na ,inteligentnych inwestycjach”. Ich celem było zapewnienie wyższej stopy wzrostu i trwałego dobrobytu w długim okresie czasu. Na realizację pakietu przeznaczono 200 mld euro, co stanowiło 1,5\% PKB UE. Pakiet zakładał spełnienie trzech celów strategicznych, którym miały służyć wskazane środki finansowe, a zaliczono do nich: szybką stymulację strony popytowej oraz przywrócenie zaufania na rynku; zmniejszenie kosztów społecznych powstałych

${ }^{25}$ EC European Economic Recovery Plan, 2008. Dostępny w Internecie: ec.europa.eu/economy.../ [online 20.07.2015r.] 
wskutek kryzysu finansowego przyspieszenie przekształcania gospodarki UE w gospodarkę niskoemisyjną. Upoważniono państwa członkowskie do podejmowania działań antykryzysowych. Komisja proponowała krajom UE konkretne rozwiązania dotyczące promowania przedsiębiorczości czy też prowadzenia badań.

Odpowiedzią na działania podjęte przez Komisję Europejską, było przygotowanie i przyjęcie przez rząd polski Planu Stabilności i Rozwoju, który miał na celu wzmocnienie gospodarki kraju w trakcie trwania kryzysu na świecie. Władze państwowe przyjęły, że pomoc finansowa dla gospodarki w latach 2009-2010 wyniesie 90 mld zł., z czego: 40 mld zostało przekazanych na wzrost limitu poręczeń i gwarancji, a 20 mld zostało przekazanych na stworzenie akcji kredytowych dla małych i średnich przedsiębiorstw za pośrednictwem BGK, który został dokapitalizowany środkami pieniężnymi w kwocie 2 mld zł. To rozwiązanie miało na celu zwiększenie dostępności kredytów dla sektora małych i średnich przedsiębiorstw. ${ }^{26}$

W sytuacji powiększającego się deficytu budżetowego rząd w Polsce podjął działania zmierzające do przywrócenia jego zrównoważenia. Od 2011 r. podwyższono stawki VAT z poziomu $7 \%$ i $22 \%$ do $8 \%$ i $23 \%$ z równoczesnym ograniczeniem katalogu dóbr, które mogły pozostać opodatkowane stawkami preferencyjnymi. W zakresie wydatków wprowadzono pewne ograniczenia np. w sferze ubezpieczeń społecznych (ograniczenie części składki emerytalnej przekazywanej z ZUS do funduszy emerytalnych z 7,3\% do 2,3\%. Rząd przyjął również rozwiązania dotyczące kwestii kosztów przeprowadzania prac badawczo - rozwojowych. Zadecydowano, że zostały one zaliczone do kosztów podatkowych i mogły być rozliczone z momentem ich poniesienia bądź poprzez dokonanie odpisów amortyzacyjnych $\mathrm{w}$ trakcie trwania inwestycji. Plan zakładał także przyspieszenie dokonania inwestycji ze środków UE w kwocie 16,8 mld zł. Narodowy Fundusz Ochrony Środowiska i Gospodarki Wodnej udostępnił ok. 1,5 mld zł. na inwestycje dotyczące odnawialnych źródeł energii. W 2009 roku przedstawiono kolejny program antykryzysowy o nazwie Działania Ministerstwa Gospodarki na rzecz stabilności i rozwoju. Główne cele programu skoncentrowano na:

- spowodowaniu wzrostu popytu konsumenckiego, przez wprowadzenie elastyczności rynku pracy, dzięki czemu miały zostać utrzymane dotychczasowe miejsca pracy;

- wywołaniu wzrostu popytu inwestycyjnego, który miał polegać na przyspieszeniu inwestycji dokonywanych $\mathrm{z}$ pomocą instytucji publicznych, dofinansowanych $\mathrm{z}$ funduszy strukturalnych i Funduszu Spójności. Wzrost miał zostać osiagnięty także, przez poprawę procedur przyznawania środków pieniężnych $\mathrm{w}$ ramach programów operacyjnych UE czy też poprawy dostępu do zewnętrznych źródeł finansowania dla przedsiębiorców;

- prowadzeniu polityki horyzontalnej, której to działania skoncentrowano na złagodzeniu wymogów administracyjnych w stosunku do tworzących się firm. ${ }^{27}$

Oba programy przygotowane przez rząd Polski wymagały doprecyzowania oraz wprowadzenia zmian $\mathrm{w}$ regulacjach prawnych, nastapiło poprzez nowelizację ustaw dotyczących finansów. Dalsze uszczegółowienie planów nastąpiło w czerwcu 2009r.

\footnotetext{
${ }^{26}$ Grosse T. G., ,Program stabilności czy rozwoju? Analizy i Opinie nr 89, Instytut Spraw Publicznych, 2009 Warszawa

${ }^{27}$ Realizacja „Planu Stabilności i Rozwoju”, Kancelaria Prezesa Rady Ministrów, Warszawa, 2009.
} 
Sejm uchwalił ustawę dotyczącą pomocy państwa w zakresie spłaty kredytów mieszkaniowych, udzielonym osobom, które straciły pracę po $01.07 .2008 \mathrm{r}$.

Pomoc otrzymał także małżonek, który nie był bezpośrednim kredytobiorca, jeśli para posiadała wspólnotę majątkową. Warunkiem uzyskania rządowej pomocy była konieczność zarejestrowania się jako osoba bezrobotna w Urzędzie Pracy i złożenie wniosku o zapomogę. Miesięczne dofinansowanie takich osób wynosiło 1200zł. Jeśli rata kredytu przekraczała tę kwotę, można było się ubiegać o dodatkowe środki pieniężne. $^{28}$

Wprowadzono również ustawę o złagodzeniu skutków kryzysu ekonomicznego dla przedsiębiorców oraz pracowników. Rozwiązania przyjęte w ustawie miały sprzyjać poprawie kondycji przedsiębiorstw, a także ochronie miejsc pracy. ${ }^{29}$ Miały również na celu załagodzenie następstw kryzysu w najbiedniejszych grupach społecznych, zagrożonych marginalizacją. Ustawa przewidziała dla przedsiębiorców dodatkowe wsparcie z Funduszu Pracy oraz Gwarantowanych Świadczeń Pracowniczych. Inne rodzaje pomocy publicznej $\mathrm{w}$ dobie kryzysu to: zgoda na wprowadzenie dłuższych okresów rozliczeniowych; możliwość wprowadzenia elastycznych godzin pracy; wprowadzenie ograniczenia w podpisywaniu umów na czas określony. Rozwiązania te umożliwiły firmom wprowadzenie zmian w organizacji czasu pracy, a poprzez wypłaty środków pieniężnych dla pracowników $\mathrm{z}$ tytułu zatrudnienia subsydiowanego ustawodawca dążył do: zmniejszenia kosztów pracy, zachowania dotychczasowych miejsc pracy; utrzymania konkurencyjności prowadzonej działalności; poprawy jakości kapitału ludzkiego dzięki wprowadzeniu systemu szkoleń i kierowaniu pracowników na studia podyplomowe. Bezpośrednią pomocą zostało objętych około 249500 zatrudnionych osób w firmach, które dotknęły przejściowe trudności finansowe, w tym 49500 osobom zrefundowano koszty podjętych studiów podyplomowych i szkolen. ${ }^{30}$

Oprócz działań podjętych przez rząd należy wymienić też działania podęte przez NBP, który w 2008 roku przedstawił pakiet zaufania zaadresowany do polskiego systemu bankowego. Plan przygotowany przez NBP opierał się na trzech strategicznych celach: umożliwieniu bankom pozyskiwania środków pieniężnych w polskich złotych, na okres dłuższy niż jeden dzień; umożliwieniu pozyskiwania środków walutowych; zwiększeniu płynności. Działania przeprowadzone przez NBP obejmowały: wprowadzenie zasilających operacji repo z maksymalnym okresem zapadalności do trzech miesięcy; wprowadzenie operacji swapów walutowych; wprowadzenie depozytu walutowego, który miał być zabezpieczeniem kredytów refinansowych; wprowadzenie większej częstotliwości przeprowadzania operacji otwartego rynku; wprowadzenie możliwości wykupienia bonów pieniężnych, przed terminem zapadalności. ${ }^{31}$

\footnotetext{
${ }^{28}$ Polsce grozi wielka dziura budżetowa, Dziennik, 2009 [w:] J. Jankowiak, M. Gronicki, Jak ograniczyć potrzeby pożyczkowe? Rzeczpospolita, 2009. Dostępny w Internecie: http://januszjankowiak.bblog.pl// [online: 10.08.2015r.]

${ }^{29}$ Ustawa z dnia 12 lutego 2009 r. o udzielaniu przez Skarb Państwa wsparcia instytucjom finansowym, Tekst ustawy ustalony ostatecznie po rozpatrzeniu poprawek Senatu. Dostępny w Internecie: http://orka.sejm.gov.pl, [online. 10.08.2015r.]

${ }^{30}$ Grosse T. G. 2009: Program stabilności czy rozwoju? Analizy i Opinie nr 89, Instytut Spraw Publicznych. Warszawa

${ }^{31}$ NBP, Polska wobec światowego kryzysu gospodarczego, Warszawa, 2009. Dostępny w Internecie: https://www.nbp.pl/publikacje/ [online 21.08.2015r.]
} 


\section{Dzialania zewnętrzne wspierające polski program antykryzysowy}

Wszystkie pakiety przyjęte w latach 2008-2009 miały na celu minimalizację negatywnych skutków światowego kryzysu finansowego, które dotknęły polską gospodarkę, a także utrzymanie zaufania do sektora bankowego. Na gospodarkę w Polsce i krajowy system finansowy silny wpływ miały także działania międzynarodowych instytucji finansowych, które także reagowały na światowy kryzys finansowy. Wśród działań na szczególną uwagę zasługują działania Międzynarodowego Funduszu Walutowego (MFW).

Głównym instrumentem stosowanym przez MFW w reakcji na kryzys było udzielane pożyczek dla krajów, w celu uzyskania dodatkowych źródeł finansowania oraz stabilizacji gospodarki. Poza funkcją kredytową, MFW pełni funkcje kontrolne w postaci nadzoru uzgodnionych programów dostosowawczych i weryfikuje cele, na jakie przeznaczane są środki kredytowe. Istotna jest również funkcja konsultacyjna - usługi konsultacyjne i współpraca krajów członkowskich w zwalczaniu problemów gospodarczych. Po wrześniu 2008 r. do MFW wpłynęła duża ilość wniosków o pożyczki. Pod koniec tego roku Fundusz udzielił pierwszej pożyczki Islandii, następnie Ukrainie, Węgrom, Łotwie, Pakistanowi i Gruzji. W roku następnym z pomocy MFW skorzystało 9 państw, w tym 4 europejskie. W 2010 roku kryzys ujawnił się wyraźnie w Grecji, która nie była w stanie zdobyć środków na rynku finansowym, by pokryć swoje zobowiązania. W pierwszym pakiecie pomocowym w wysokości 110 mld euro przyznanym w 2011 r., MFW partycypował w kwocie 30 mld euro. Fundusz uczestniczył także w jednej trzeciej w drugim pakiecie w 2012 roku w łącznej kwocie 130 mld euro. Trzeci pakiet pomocowy, ustalony w sierpniu 2015 r., opiewa na kwotę ok. 85 mld euro. Drugim krajem, który uzyskał istotną pomoc finansową z MFW była Irlandia, która pod koniec 2010 roku otrzymała pożyczkę w kwocie 85 mld euro. Udział MFW oraz Europejskiego Mechanizmu Stabilizacji Finansowej w tej pożyczce wyniósł 22,5 mld. W 2011 roku z pakietu finansowego skorzystała Portugalia w kwocie 78 mld euro, z czego jedna trzecia pochodziła z MFW, a 24,3 mld z Unii Europejskiej ${ }^{32}$.

Działania antykryzysowe podejmowała również Unia Europejska. W ramach tych działań należy wskazać dwa główne filary: regulacyjny i instytucjonalnofinansowy. W filarze regulacyjnym należy na wymienić reformę regulacji ostrożnościowych, mających na celu ustabilizowanie $\mathrm{i}$ wzmocnienie instytucji kredytowych. Kluczowym wydarzeniem jest tu uchwalenie w czerwcu 2013 roku tak zwanego Pakietu CRD IV, złożonego z dwóch aktów prawnych: Regulacji UE nr 575/2013 w sprawie wymogów ostrożnościowych dla instytucji kredytowych i firm inwestycyjnych (CRR) oraz Dyrektywy UE 2013/36/UE w sprawie warunków dopuszczenia instytucji kredytowych do działalności oraz nadzoru ostrożnościowego nad instytucjami kredytowymi i firmami inwestycyjnymi. Głównym celem regulacji jest podwyższenie zdolności sektora finansowego w krajach Unii do absorpcji szoków finansowych i ekonomicznych, poprzez podwyższenie zasobów finansowych zabezpieczających ryzyko oraz podniesienie jakości procesu zarządzania ryzykiem. Główne kierunki reformy odnosiły się do: zwiększenia poziomu funduszy własnych

\footnotetext{
32 NBP, Programy pomocowe dla Grecji, Irlandii i Portugalii - stan na sierpień 2011 r. Dostępny $w$ internecie: https://www.nbp.pl/ [online 30.09.2015]
} 
banków, mających za zadanie amortyzację potencjalnych strat i podniesienia finansowania gospodarki realnej; wymaganie utrzymywania odpowiedniego poziomu płynności; ograniczania ryzyka, dzięki restrykcjom nałożonym na wskaźnik dźwigni finansowej; zmian w polityce wynagradzania osób zajmujących się zarządzaniem ryzykiem, poprzez zniechęcanie do podejmowania nadmiernego ryzyka; usprawnienia ładu korporacyjnego oraz zwiększenia stopnia przejrzystości działania.

Obok regulacji ostrożnościowych, na płaszczyźnie wspólnotowej został uregulowany zupełnie nowy obszar - działania sanacyjne, restrukturyzacja i likwidacja instytucji finansowych. Służy temu uchwalona w 2014 r. dyrektywa w sprawie naprawy i likwidacji instytucji kredytowych i firm inwestycyjnych. Celem regulacji jest nałożenie obowiązku opracowania realistycznych planów naprawczych przez instytucje finansowe oraz stworzenie jednolitego procesu prowadzenia szybkiej i uporządkowanej restrukturyzacji i upadłości, przy ścisłej współpracy europejskich i krajowych organów nadzoru. Istotnie wzmocniony został też europejski system gwarantowania depozytów, przez uchwalenie w 2014 roku odpowiedniej dyrektywy.

Podkreślenia wymaga także wdrożenia tzw. „Single Rulebook” (jednolity zbiór zasad). Celem tego zbioru jest wyeliminowanie występujących przed kryzysem istotnych różnic w regulacjach działalności bankowej i inwestycyjnej w krajach członkowskich. Uważa się, że różnice te były jedną z wyraźnych przyczyn kryzysu, przez brak pewności prawnej, wykorzystywanie przez banki różnic interpretacyjnych w różnych legislacjach, utrudnianie konkurencji i funkcjonowania jednolitego rynku europejskiego. SR oznacza stosowanie jednolitych definicji, pojęć i parametrów regulacyjnych, tych samych metod pomiaru ryzyka (np. wymogów kapitałowych) oraz tej samej interpretacji danego przepisu na terenie UE.

W filarze instytucjonalno-finansowym, działania koncentrowały się z jednej strony na udzielaniu pożyczek dla rządów zagrożonych krajów - we współpracy z MFW i Europejskim Bankiem Centralnym, a z drugiej strony - na stworzeniu instytucji mających na celu poprawę koordynacji wysiłków zmierzających do zapobiegania i zwalczania kryzysów finansowych oraz koordynację i poprawę efektywności udzielanej pomocy finansowej.

Zmiany instytucjonalne $\mathrm{w}$ architekturze systemu bezpieczeństwa $\mathrm{w}$ Europie wprowadzone $\mathrm{W}$ odpowiedzi na kryzys finansowy objęły przede wszystkim ustanowienie Europejskiego Systemu Nadzoru Finansowego, Mechanizmu Restrukturyzacji i Likwidacji, Europejskiego Mechanizmu Stabilizacyjnego i Jednolitego Mechanizmu Nadzorczego.

\section{Wnioski}

1. Na współczesny kryzys finansowy, zwany wielką recesją złożyły się różnego rodzaju nieprawidłowości, które narastały w sektorze finansowym wielu krajów świata, a zwłaszcza w sektorze bankowym i w sektorze nieruchomości USA. Wśród całego kompleksu przyczyn do najważniejszych zalicza się nadmierną akcję kredytową przy niewłaściwej ocenie ryzyka, w tym ryzyka związanego z procesem sekurytyzacji.

2. Mimo podjętych działań zaradczych i naprawczych instytucji finansowych i rządu USA kryzys rozprzestrzenił się szybko na inne kraje świata, zwłaszcza kraje 
wysokorozwinięte, objął także gospodarki wschodzące, w tym Polskę. Zjawiska kryzysu finansowego w Polsce ujawniły się z opóźnieniem i miały łagodniejszy przebieg.

3. Globalny kryzys finansowy lat 2007-2011 dotknął swoimi skutkami przedsiębiorstwa, gospodarstwa domowe oraz instytucje państwowe i samorządowe. Ujawnił się w spowolnieniu wzrostu gospodarczego, zwłaszcza w roku 2008 gdy nastąpiły spadki indeksów giełdowych i wysokie straty przedsiębiorstw i w roku 2009, w którym zanotowano najniższe wskaźniki dotyczące wzrostu PKB i obniżenie popytu krajowego. W układzie makroekonomicznym można zauważyć także drugą, opóźnioną falę skutków kryzysu przypadającego na lata 2012-2013.

4. Działania antykryzysowe i naprawcze w Polsce podejmowane były przez rząd, jego instytucje oraz Narodowy Bank Polski. Wynikały one także z działań adaptacyjnych i dostosowawczych podmiotów gospodarczych i samorządów terytorialnych. Polskie działania były prowadzone przy współdziałaniu z instytucjami Unii Europejskiej i międzynarodowymi instytucjami finansowymi. Działania antykryzysowe i zapobiegawcze dotyczyły zarówno sfery instytucjonalnej, sposobu funkcjonowania systemu finansowego i prowadzenia polityki finansowej, jak też dostosowań w realnej sferze gospodarki.

\section{BIBLIOGRAFIA}

Adamczyk. M, Współczesny kryzys finansowy - przyczyny i konsekwencje dla gospodarki światowej. [w:] http://ekonom.ug.edu.pl/ [online:31.03.2015r.]

Centrum Badania Opinii Społecznej, Reakcje na kryzys gospodarczy 2009, Komunikat z badań, Warszawa

Costa Navajas M., A. Thegeya, 2013, Financial soundeness Indicators and Banking Crisis, IMF Working Papers, No 13/263 s.28

Czekaj J., Wpływ światowego kryzysu gospodarczego na polska gospodarke, [w:] G. Kołodko (red.), Globalizacja, kryzys i co dalej?, Poltext Sp. z o.o., Warszawa, 2010.

EC European Economic Recovery Plan 2008, Dostępny w Internecie ec.europaeconomy (online 20.07.2015)

Falkowski. K, , Teichmann. E (red.), Państwa bałtyckie i Europy Wschodniej. Reakcja na światowy kryzys gospodarczy i regionalny kryzys gazowy, SGH, Warszawa, 2010, s.50-55

Global Financial Stability Report, 2010, International Monetary Fund, Washington DC April. [w:] https://www.imf.org/external/pubs/ft/gfsr/.

Grosse T. G.: Program stabilności czy rozwoju? Analizy i Opinie nr 89, Instytut Spraw Publicznych. (2009) Warszawa

Gruszczyńska-Brożbar. E., Funkcjonowanie GPW w Warszawie w świetle światowego kryzysu finansowego, w: Finanse - Teoria i praktyka. Rynki finansowe i ubezpieczenia, Zeszyty Naukowe nr 550, Ekonomiczne Problemy Usług nr 40, Wyd. Nauk. Uniwersytetu Szczecińskiego, Szczecin, 2009.

GUS Stopa bezrobocia w latach 1990-2015, Dostęp w Internecie http://stat.gov.pl (online 15.05.2015)

GUS, Rachunki kwartalne PKB w latach 2007-2013. Dostęp w Internecie stat.gov.pl (online 10.04.2015)

GUS, Raport o stanie sektora małych i średnich przedsiębiorstw. [w:] www.pi.gov.pl (online 21.08.2015) 
Iwanicz-Drozdowska M, 2015, Restrukturyzacja banków Unii europejskiej w czasie globalnego kryzysu finansowego, Oficyna Wydawnicza SGH, Warszawa

Komisja Nadzoru Finansowego. Informacja o sytuacji banków po trzech kwartałach 2008 r. Dostęp w Internecie http://www.knf.pl (online 14.03.2015)

Konopczak M., Sieradzki R., Wiernicki M., Kryzys na światowych rynkach finansowych - wpływ na rynek finansowy w Polsce oraz implikacje dla sektora realnego, „Bank i Kredyt”, nr 6, 2010.

Kumhof M., J. Zoltan: The truth about Banks FD Finance and Development, A Quarterly Publication of the International Monetary Fund, March 2016, Volume 53, Number 1, s.50-53

Ministerstwo Finansów, Informacje kwartalne o sytuacji makroekonomicznej i stanie finansów publicznych, Dostęp w Internecie www.wneiz.pl/nauka

Miszkin. F.S., Ekonomika pieniadza, bankowości i rynków finansowych, PWN, Warszawa 2002.

Nawrot. W., Globalny kryzys finansowy XXI wieku. Przyczyny, przebieg, skutki, prognozy, Wyd. CeDeWu, Warszawa, 2009.

NBP Programy pomocowe dla Grecji, Irlandii i Portugalii - stan na sierpień 2011. Dostęp w Internecie http://www.nbp.pl (online 30.09.2015)

NBP, Polska wobec światowego kryzysu gospodarczego, Warszawa, 2009. Dostęp w Internecie (online 21.08.2015)

Nieborak T., Globalny kryzys finansowy, istota, przyczyny, konsekwencje. Ruch Prawniczy, Ekonomiczny i Socjologiczny, $\mathrm{Nr} 42010$

Orłowski. W., Pasternak. R., Flaht. K., Szubert. D., Procesy inwestycyjne i strategie przedsiębiorstw $w$ czasach kryzysu, Projekt współfinansowany przez Unię Europejską w ramach Europejskiego Funduszu Społecznego, Polska Agencja Rozwoju Przedsiębiorczości, Warszawa, 2010.

Podstawowe Statystyki GPW. Dostęp w Internecie http://www.gov.pl (online 30.04.2015)

Realizacja „Planu Stabilności i Rozwoju”, Kancelaria Prezesa Rady Ministrów, Warszawa, 2009. Dostęp w Internecie http://kprm.pl (online 05.2015)

Rok kryzysu. Co dalej? Wyzwania stojące przed spółkami, Pricewaterhouse Coopers, Warszawa, 2009. [w:] https://www.pwc.pl/pl/

Rosati. D., Przyczyny i mechanizmy kryzysu finansowego w USA w latach 2007-2009, [w:] G.

Kołodko (red.), Globalizacja, kryzys i co dalej? Poltext Sp. z o.o., Warszawa, 2009.

Satoła Ł. Kryzys finansów publicznych z perspektywy społeczności lokalnej. Roczniki Naukowe SERiA Tom XIV zeszyt 4, s. 104-109

Sławiński. A., Przyczyny globalnego kryzysu bankowego, Materiały konferencyjne pt. Nauki społeczne wobec kryzysu na rynkach finansowych, Kolegium Ekonomiczno-Społeczne Szkoły Głównej Handlowej, Warszawa, 2008.

Sytuacja na rynku kredytowym. Wyniki ankiety dla przewodniczących komitetów kredytowych. Departament Systemu Finansowego NBP, Warszawa, Warszawa 2009 http://www.nbp.pl (online 15.05.2015)

Wojtyna. A (red), Kryzys finansowy i jego skutki dla krajów na średnim poziomie rozwoju, PWE, Warszawa, 2011, s.180.

\section{Summary}

Description and evaluation of the world financial crisis of the years 2007-2011, as well as pheatures and outcomes of this crisis in Poland and anticrisis activities undertaken by the government and financial institutions in Poland represent the subject and purpose of this article. The subject literature and informations from different national and international financial 
institutions and organizations were used as a source of research materials and data for analysis. Financial crisic appeared in Poland with some delay and was less intensive than in other developed countries. Anticrisis measures undertaken in Poland were adjusted to the European Union and International Monetary Fund recomendations. Polish Central Bank and government anticrisis activities referred to institutional sphere, mode of institution functioning and the area of financial policy. Reaction of enterprises, households, selfgoverning and public institutionas acting in real economy were observed and assessed.

Key words: financial crisis, great recession, anticrisis activities, financial policy

Informacja o autorach:

Prof. dr hab. Mieczyslaw Adamowicz

Państwowa Szkoła Wyższa im. Papieża Jana Pawła II w Białej Podlaskiej

e-mail: adamowicz.mieczyslaw@gmail.com

Wioletta Miklaszewska

Szkoła Główna Gospodarstwa Wiejskiego w Warszawie

Tomasz Adamowicz

Państwowa Szkoła Wyższa im. Papieża Jana Pawła II w Białej Podlaskiej 